\title{
High matrix vegetation decreases mean seed dispersal distance but increases long wind dispersal probability connecting local plant populations in agricultural landscapes
}

Research

Keywords:

Posted Date: June 2nd, 2021

DOI: https://doi.org/10.21203/rs.3.rs-278304/v2

License: (1) This work is licensed under a Creative Commons Attribution 4.0 International License. Read Full License 


\section{Abstract}

The authors have requested that this preprint be withdrawn due to a need to make corrections.

\section{Full Text}

The authors have withdrawn this preprint from Research Square. 